\title{
Stimulation of amphibian gastroduodenal bicarbonate secretion by sucralfate and aluminium: role of local prostaglandin metabolism
}

\author{
J R CRAMPTON, L C GIBBONS, AND W D W REES \\ From the University of Department of Medicine Addenbrooke's Hospital, Cambridge and Department of \\ Gastroentrology, Hope Hospital, University of Manchester, School of Medicine, Salford
}

Summary The present studies were designed to explore the possible mode of protective and ulcer healing actions of sucralfate by examining its effect on gastroduodenal bicarbonate secretion by isolated amphibian mucosa. Luminal sucralfate $(0.5 \mathrm{~g} / \mathrm{l})$ significantly increased bicarbonate secretion by fundic and antral mucosa without influencing transmucosal potential difference. Significant stimulation of duodenal bicarbonate secretion occurred only at $1.0 \mathrm{~g} / \mathrm{l}$ without change in potential difference. Aluminium, a component of sucralfate, produced similar increases in bicarbonate secretion, while the sucrose and sulphate components were without effect. Pretreatment of mucosae with the cyclooxygenase inhibitor, indomethacin $\left(10^{-5} \mathrm{M}\right)$ did not abolish the secretory response to sucralfate or aluminium. The results suggest that stimulation of gastroduodenal bicarbonate secretion, possibly by the aluminium moeity of sucralfate, may play a role in its protective and ulcer healing actions.

Sucralfate is a basic aluminium salt of sucrose sulphate and has been shown to protect gastric mucosa from experimental damage, ${ }^{1}$ prevent bleeding from stress ulceration, ${ }^{2}$ and heal peptic ulcers. ${ }^{3+}$ The drug was initially thought to act by adhering to ulcerated tissue and forming a physical barrier to injury by acid, pepsin, and bile salts. ${ }^{5-7}$ Recent evidence has suggested that sucralfate may have a direct protective action on the gastroduodenal mucosa, possibly mediated by changes in local prostaglandin $\mathrm{E}_{2}$ metabolism. ${ }^{*}$ Such an action may be shared by other compounds containing aluminium such as antacids, raising the possibility that this component may be vital to the protective action of sucralfate. ${ }^{9}$ The current series of experiments were designed to further explore the mechanism of mucosal protection by sucralfate by studying its action and that of aluminium on gastroduodenal bicarbonate secretion, an important component of the 'mucus-bicarbonate' barrier."'

Address for correspondence: Dr W D W Rees, Hope Hospital, Fccles Old Road, Salford M6 8HD

Received for publication 13 January 1988.

\section{Methods}

FROGS

The studies on gastroduodenal bicarbonate secretion were performed on gastric and duodenal mucosal obtained from either Rana temporaria (Xenopus, UK) or Rana catesbeiana (St Croix Biologicals, Minneapolis, Minnesota, USA). All animals were kept at $21^{\circ} \mathrm{C}$ and used within three weeks of purchase.

STUDIES ON GASTRIC MUCOSA

The method used to measure electrical and secretory activity of gastric mucosa has been previously described in detail." Briefly, gastric mucosa was dissected free from its muscularis externa and mounted as a membrane (surface area $1.8 \mathrm{~cm}$ ) between two halves of a perspex chamber. Each surface was bathed with $20 \mathrm{ml}$ solution circulated by means of gas lifts. The unbuffered luminal side solution was gassed with $100 \%$ oxygen and the buffered serosal side solution with a mixture of $95 \%$ oxygen and $5 \%$ carbon dioxide. The $\mathrm{pH}$ of the 
luminal side solution was maintained at $\mathrm{pH} 7.40$ by the addition of $5 \mathrm{mM}$ hydrocholoric acid from a $\mathrm{pH}$ stat system (ABU 13 and TT2, Radiometer, Copenhagen, Denmark).

Spontaneous output of acid by fundic mucosa was inhibited by adding $10^{-3} \mathrm{M}$ cimetidine to the serosal side solution. Antral mucosa spontaneously secreted alkali. Transmucosal potential difference was measured by means of matched electrodes (Russel Electrodes, Fife, Scotland) and continually recorded while electrical resistance was determined from the fall in recorded potential difference produced by passing a $30 \mu \mathrm{A}$ current through the tissue via silver/silver chloride electrodes. The mucosal and serosal solutions were maintained at $20^{\circ} \mathrm{C}$ by water jackets perfused by a Haake $\mathrm{G}$ circulator (Karlsrutie, W. Germany).

STUDIES ON DUODENAL MUCOSA

The duodenal mucosa was stripped of muscularis externa and mounted as an intact tube on glass cannulae as previously described. ${ }^{12}$ The luminal surface was bathed with $10 \mathrm{ml}$ unbuffered solution, circulated by $100 \%$ oxygen gas lift and maintained at $\mathrm{pH} 7.40$ using $\mathrm{pH}$ stat titration as described above. The serosal surface was bathed with $120 \mathrm{ml}$ buffered solution gassed with a mixture of $95 \%$ oxygen and $5 \%$ carbon dioxide. Transmucosal potential difference was measured and recorded as described above and the bathing solutions maintained at $20^{\circ} \mathrm{C}$.

\section{BATHING SOLUTIONS}

The serosal solution bathing gastric and duodenal mucosae contained $\mathrm{Na}^{\prime}, 102.4 \mathrm{mM} ; \mathrm{K}^{+}, 4.0 \mathrm{mM}$; $\mathrm{Ca}^{2+}, 1.8 \mathrm{mM} ; \mathrm{Mg}^{2+}, 0.8 \mathrm{mM} ; \mathrm{Cl}, 91.4 \mathrm{mM}$; $\mathrm{HCO}_{3}, 17.8 \mathrm{mM} ; \mathrm{H}_{2} \mathrm{PO}_{4}^{-}, 0.8 \mathrm{mM} ; \mathrm{SO} 2_{4}^{2-}, 0.8$ $\mathrm{mM}$; and glucose $2 \mathrm{mM}$ (Osmolarity $=220$ mosmol and $\mathrm{pH}=7 \cdot 20$ ). The luminal solution differed in that $\mathrm{HCO}_{3}^{-}$and $\mathrm{H}_{2} \mathrm{PO}_{4}^{-}$were replaced by mannitol $(11.3 \mathrm{mM})$ to maintain the osmolarity. Titrant acid was identical to luminal solution except for the addition of $5 \times 10{ }^{3} \mathrm{M}$ hydrochloric acid.

\section{DRUGS AND CHEMICALS}

Sucralfate was obtained as the amorphous powder (Ayerst Laboratories, Hampshire, England) and prepared at room temperature as a suspension in saline so that additions of $200 \mu \mathrm{l}$ to bathing solutions produced final concentrations in the range of $0 \cdot 1$ to $1 \mathrm{~g} / \mathrm{l}$. Although sucralfate possessed little buffering capacity, the suspensions were titrated to $\mathrm{pH} \mathrm{7.40}$ before addition to the chamber solutions. The $\mathrm{pH}$ of such suspensions remained stable and additions to gassed luminal solution in the absence of tissue did not alter the $\mathrm{pH}$.

Indomethacin (Sigma Chemicals Ltd, England)
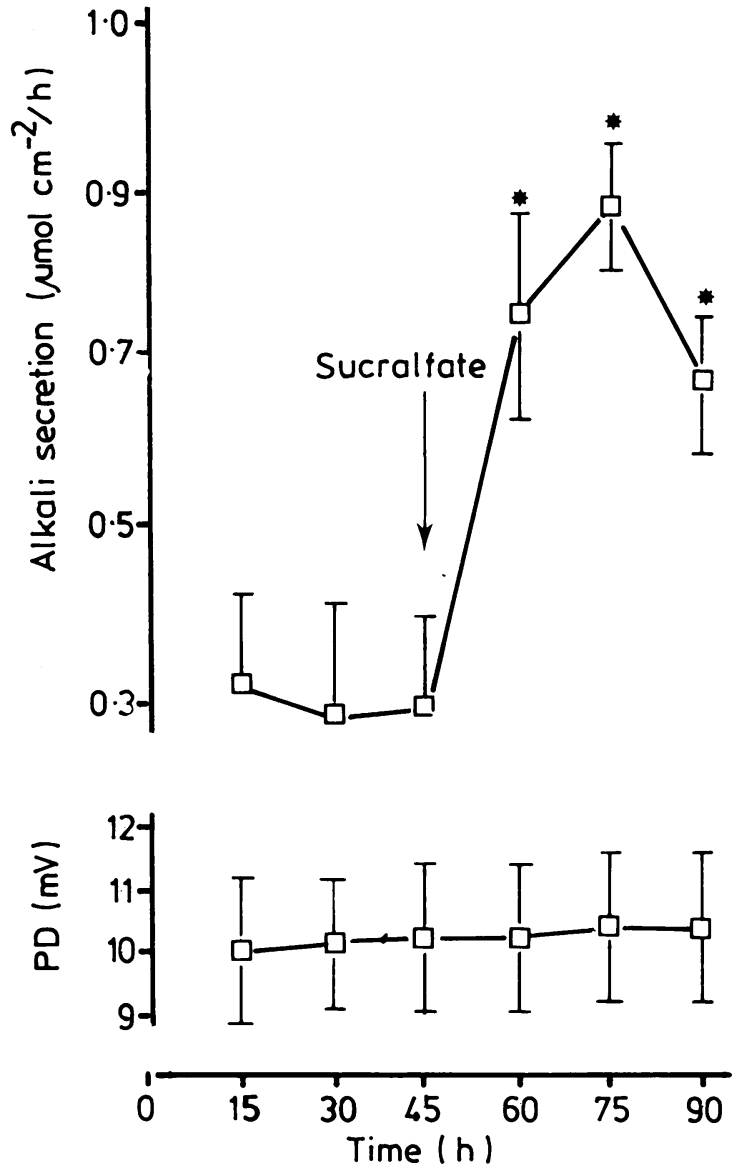

Fig. 1 Effect of luminal sucralfate $(0 \cdot 5 \mathrm{~g} / \mathrm{l})$ on alkalinisation and transmucosal PD of fundic mucosa $(n=4$, mean $(S E)$, * $p<0 \cdot 05)$.

was prepared as a stock solution and added to the serosal side solution to produce a concentration range between $10^{-6}$ and $10^{-4} \mathrm{M}$.

Aluminium, in the form of aluminium potassium sulphate and aluminium acetate (Sigma Chemicals Ltd, England), was also prepared as stock solutions $(\mathrm{pH} \mathrm{7.40)}$ which did not disturb the $\mathrm{pH}$ equilibrium of the luminal solution, in the concentrations used. Potassium sulphate and sucrose (Sigma Chemicals Ltd) were prepared in a similar manner. Sucrose octasulphate (Ayerst Laboratories, Hampshire, England) was prepared to produce final luminal concentrations of 0.5 and $1.0 \mathrm{~g} / \mathrm{l}$.

STATISTICAL ANALYSIS

Secretory rates before and after the addition of drugs to the mucosa were compared by a paired $t$ test. Values are expressed as mean (SE). 

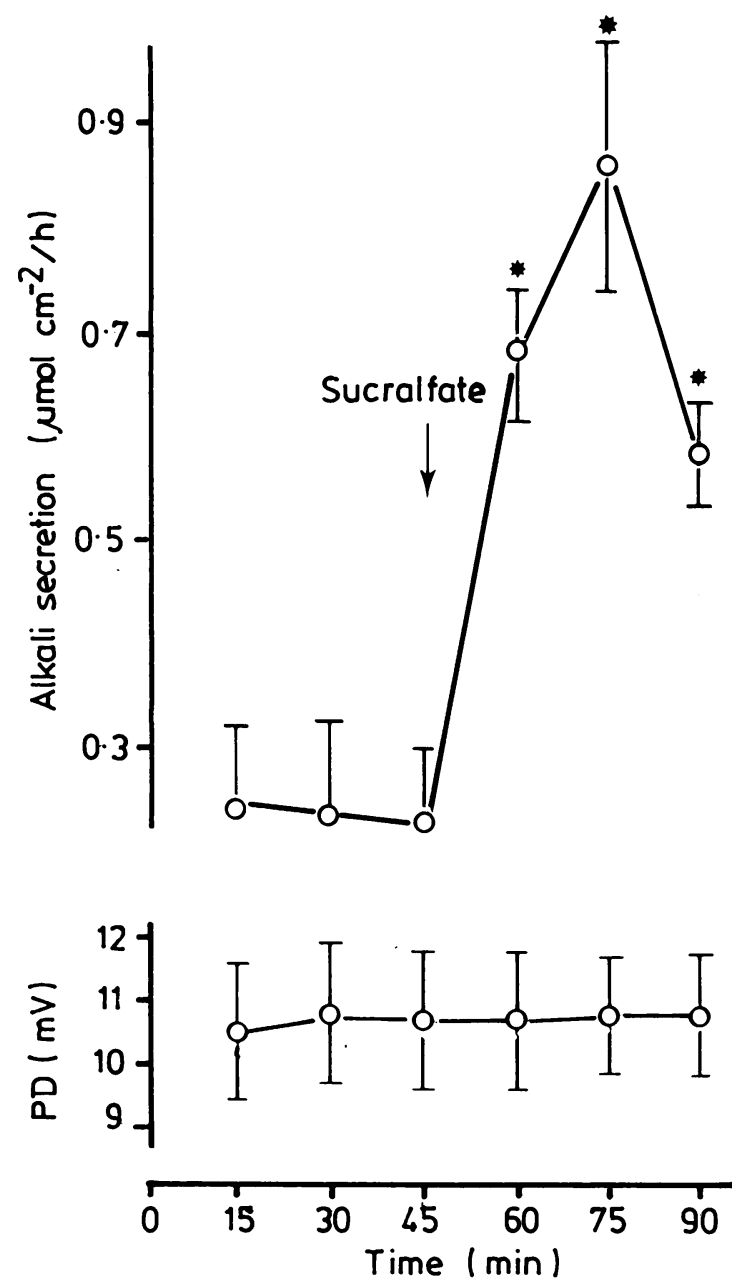

Fig. 2 Effect of luminal sucralfate $(0.5 \mathrm{~g} / \mathrm{l})$ on alkalinisation and transmucosal $P D$ of antral mucosa $\left(n=4\right.$, mean $(S E)$, ${ }^{*}$ $\left.(S E),{ }^{*} p<0 \cdot 05\right)$.

\section{Results}

In studies on Rana catesbeiana, sucralfate $(0.5 \mathrm{~g} / \mathrm{l})$ increased the rate of alkaline secretion by fundic mucosa from $0.23(0.08)$ to $0.68(0.10) \mu \mathrm{mol} / \mathrm{cm}^{2} / \mathrm{h}$ $(\mathrm{p}<0 \cdot 005, \mathrm{n}=4)$ and antral mucosa from $0.29(0 \cdot 10)$ to $0.75(0.10) \mu \mathrm{mol} / \mathrm{cm}^{2} / \mathrm{h} \quad(\mathrm{p}<0.05, \mathrm{n}=4)$ when added to the luminal solution. The transmucosal potential difference and electrical resistance across these tissues were not altered (Figs 1,2). In separate experiments, gastric mucosa from Rana temporaria exhibited a linear dose response to sucralfate in the concentration range $0 \cdot 125-0 \cdot 5 \mathrm{~g} / \mathrm{l}$ (Fig. 3). The increased rate of secretion was not transient but persisted during the period of observation (Figs 1,2).

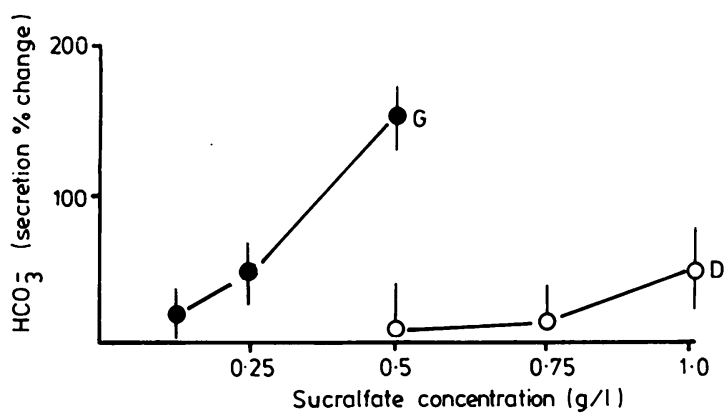

Fig. 3 Dose response curves to sucralfate for duodenal ( $D)$ and gastric mucosa $(G)$. Each point represents mean $(S E)$ change in secretion ( $n=4$ for $G, n=6$ for $D)$.

These concentrations of sucralfate, however, did not influence duodenal bicarbonate secretion.

At a higher concentration of $1 \mathrm{~g} / \mathrm{l}$, sucralfate significantly increased duodenal alkali secretion (Rana catesbeiana) from $1.16(0.30)$ to $1.69(0.30)$ $\mu \mathrm{mol} / \mathrm{h} \quad(\mathrm{p}<0 \cdot 05, \mathrm{n}=6)$ without altering transmucosal potential difference (Fig. 4). In dose response studies, a linear relationship between rate of secretion and concentration used was observed, although compared with the gastric studies the curve was shifted to the right (Fig. 3). Addition of sucralfate $(0.5$ to $1.0 \mathrm{~g} / \mathrm{l})$ to the serosal solutions of gastric or duodenal mucosa did not alter the rate of alkali secretion (results not shown).

STUDIES OF COMPONENTS OF SUCRALFATE In Rana catesbeiana, addition of $3 \times 10^{-3} \mathrm{M}$ aluminium potassium sulphate (equivalent to the total aluminium content of $0.05 \mathrm{~g} / \mathrm{l}$ sucralfate), to the luminal solution, increased alkali secretion by fundic $\left(0.79(0.30)\right.$ to $2.04(0.50) \mu \mathrm{mol} / \mathrm{cm}^{2} / \mathrm{h}, \mathrm{p}<0.05$, $\mathrm{n}=4)$ and duodenal mucosa $(1.29(0.50)$ to 2.83 $(0.60) \mu \mathrm{mol} / \mathrm{h}, \mathrm{p}<0 \cdot 05, \mathrm{n}=6)$ without altering transmucosal potential difference (Figs 5,6). Using gastric mucosa from Rana temporaria, the addition of aluminium acetate $\left(3 \times 10^{-3} \mathrm{M}\right)$ caused a similar stimulation of alkali secretion $(0 \cdot 11(0 \cdot 01)$ to 0.42 $\left.(0 \cdot 04) \mu \mathrm{mol} / \mathrm{cm}^{2} / \mathrm{h}, \mathrm{n}=6, \mathrm{p}<0 \cdot 05\right)$.

Addition of sucrose or potassium sulphate (sucrose and sulphate concentrations equivalent to those found in $0.5 \mathrm{~g} / \mathrm{l}$ sucralfate) to the luminal solution of gastric mucosa from Rana temporaria failed to alter alkali secretion or transmucosal potential difference. Furthermore addition of sucrose osctasulphate to the luminal solution failed to significantly increase alkalinisation in concentrations of $0.5 \mathrm{~g} / \mathrm{l}(0.44(0 \cdot 1)$ to $\left.0.51(0.1) \mu \mathrm{mol} / \mathrm{cm}^{2} / \mathrm{h}, \mathrm{n}=7, \mathrm{p}: \mathrm{NS}\right)$ and $1 \mathrm{~g} / \mathrm{l}(0.42$ $(0 \cdot 1)$ to $\left.0.43(0 \cdot 1) \mu \mathrm{mol} / \mathrm{cm}^{2} / \mathrm{h}\right)$.

In separate experiments, addition of sucralfate $(0.5$ to $1.0 \mathrm{~g} / \mathrm{l})$ to a chamber containing an inert 


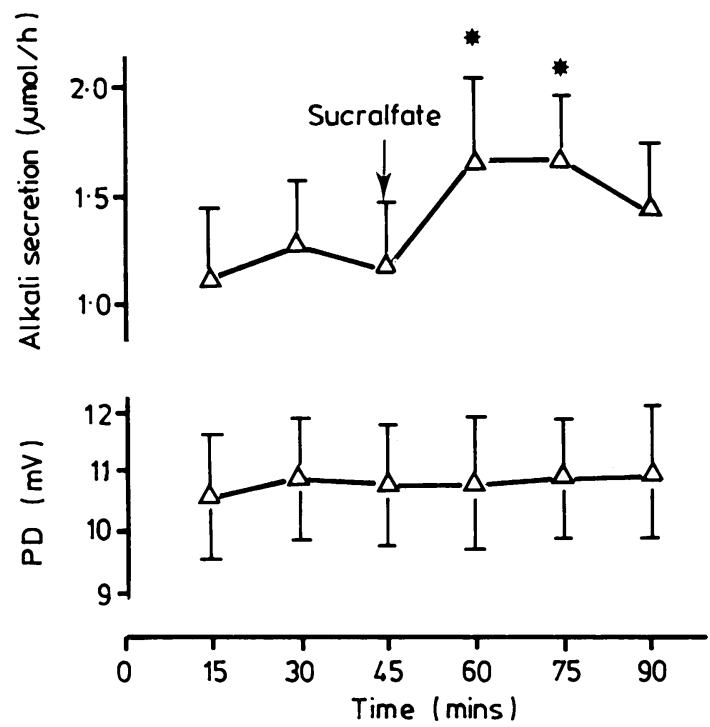

Fig. 4 Effect of luminal sucralfate $(1 \mathrm{~g} / \mathrm{l})$ on alkalinisation and transmucosal PD of duodenal mucosa $(n=6$, mean mean $\left.(S E),{ }^{*} p<0 \cdot 05\right)$.

membrane (latex rubber) instead of viable mucosa did not result in titrable alkalinity, confirming that sucralfate did not disturb the $\mathrm{pH}$ stability of luminal solution.

\section{MECHANISMS OF ALKALI SECRETION BY SUCRALFATE}

Because the increase in gastroduodenal alkali secretion was not accompanied by changes in transmucosal potential difference, the secretory response is unlikely to result from mucosal damage, increasing passive bicarbonate diffusion, or electrogenic transport of bicarbonate across epithelial cell membrane. To confirm that the secretory response is dependant on a cellular transport mechanism, the effect of the metabolic inhibitor dinitrophenol $\left(10^{-4} \mathrm{M}\right)$ on the sucralfate effect was studied. Addition of dinitrophenol to gastric mucosa from Rana temporaria (serosal side solution) reduced basal alkali secretion from $0.28(0.05)$ to $0.13(0.02) \mu \mathrm{mol} / \mathrm{cm}^{2} / \mathrm{h}, \mathrm{p}<0.05$, $\mathrm{n}=4)$ and transmucosal potential difference from $14.2(1.8)$ to $3.9(0.5) \mathrm{mV}(\mathrm{p}<0.05, \mathrm{n}=4)$. Subsequent addition of sucralfate $(0.5 \mathrm{~g} / \mathrm{l})$ to the luminal solution failed to increase the rate of alkalinisation $\left(0 \cdot 13(0.03)\right.$ to $\left.0 \cdot 12(0 \cdot 02) \mu \mathrm{mol} / \mathrm{cm}^{2} / \mathrm{h}, \mathrm{n}=4, \mathrm{p}: \mathrm{NS}\right)$.

ROLE OF ENDOGENOUS PROSTAGLANDINS IN THE RESPONSE TO SUCRALFATE AND ALUMINIUM

At concentrations of $10^{-6} \mathrm{M}$ and $10^{-5} \mathrm{M}$, serosal side application of indomethacin did not prevent the

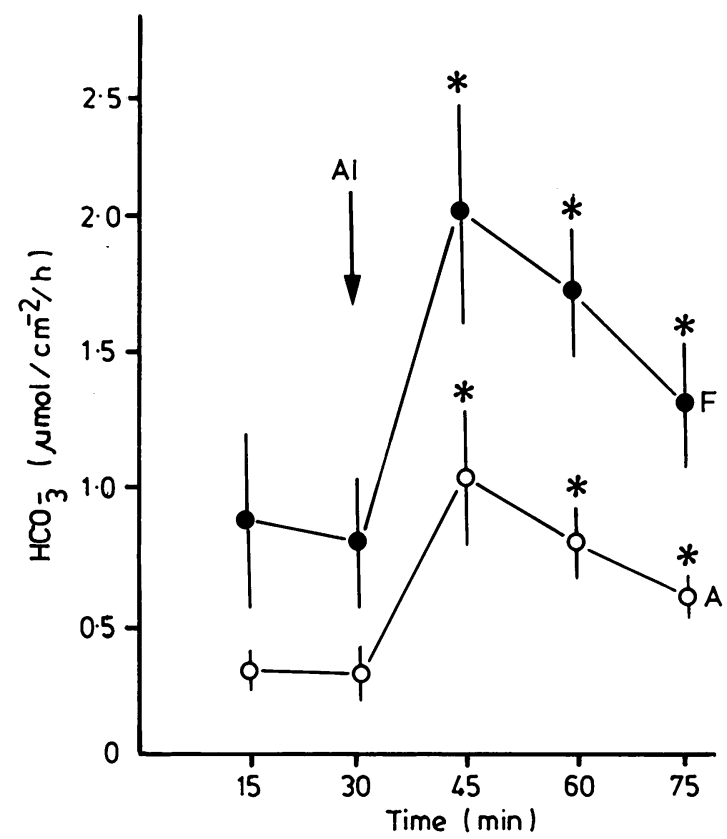

Fig. 5 Effect of luminal aluminium $\left(3 \times 10^{-3} \mathrm{MO}\right.$ on alkalinisation by fundic $(F)$ and antral $(A)$ mucosa $(n=4$, mean $\left.(S E)^{*}, p<0.05\right)$.

increase in gastric alkali secretion (Rana temporaria mucosa) produced by $0.5 \mathrm{~g} / \mathrm{l}$ sucralfate $(0 \cdot 17(0 \cdot 07)$ to $1.00(0.06) \mu \mathrm{mol} / \mathrm{cm}^{2} / \mathrm{h}, \mathrm{n}=6, \mathrm{p}<0.05$ with $10^{-5} \mathrm{M}$ indomethacin) or duodenal alkali secretion (Rana catesbeiana mucosa) produced by $1.0 \mathrm{~g} / \mathrm{l}$ sucralfate $(0.77(0.08)$ to $2.08(0 \cdot 17) \mu \mathrm{mol} / \mathrm{h}, \mathrm{n}=6, \mathrm{p}<0.05$ with $10^{-5} \mathrm{M}$ indomethacin).

The response to $3 \times 10^{-3} \mathrm{M}$ aluminium potassium sulphate was also not affected by $10^{\circ}$ and $10^{\circ} \mathrm{M}$ indomethacin (gastric: $0.10(0.01)$ to $0.48(0.20)$ $\mu \mathrm{mol} / \mathrm{cm}^{2} / \mathrm{h}, \mathrm{n}=6, \mathrm{p}<0 \cdot 05$ : duodenal: $1 \cdot 13(0 \cdot 03)$ to $1.76(0 \cdot 10) \mu \mathrm{mol} / \mathrm{h}, \mathrm{n}=6, \mathrm{p}<0 \cdot 05$ : both series with $10^{-5} \mathrm{M}$ indomethacin). At the high concentration of $10^{-4} \mathrm{M}$, indomethacin did abolish the alkali response to sucralfate by gastric and duodenal mucosa, but did not influence the aluminium responses. (Results not shown.)

\section{Discussion}

The results show that sucralfate and aluminium salts are capable of increasing alkali secretion from gastroduodenal mucosa by a prostaglandin independant mechanism. The secretory responses to sucralfate and aluminium were not associated with any alteration in transmucosal potential difference or electrical resistance (gastric mucosa only) implying that the transport of bicarbonate was neither electrogenic nor 


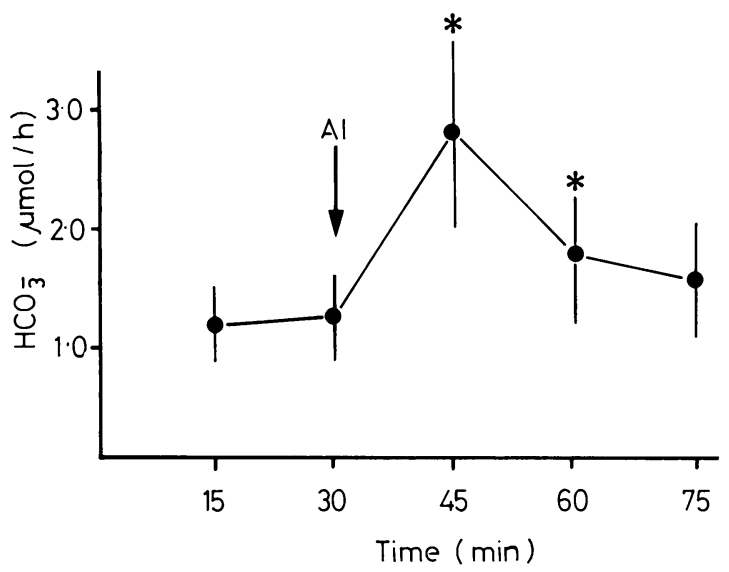

Fig. 6 Effect of luminal aluminium $\left(3 \times 10^{-3} \mathrm{M}\right)$ on alkalinisation by duodenal mucosa $(n=6$, mean $(S E)$, $p<0 \cdot 05)$.

a result of increased passive diffusion across damaged epithelium. In support of a transcellular transport process dependant on oxidative metabolism was the observation that sucralfate stimulated alkali secretion was prevented by pretreatment of mucosa with dinitrophenol. Although not definitively proved, it seems likely that sucralfate and aluminium stimulate bicarbonate secretion by an electroneutral ion exchange mechanism, such as $\mathrm{Cl} / \mathrm{HCO}_{3}$ exchange. Such an exchange mechanism has been shown to account for the bulk of basal gastric bicarbonate secretion and may be activated in duodenal mucosal by encephalins, gastric inhibitory polypeptide and glucagon..$^{.1-13}$

The finding that aluminium salts stimulate gastroduodenal bicarbonate secretion by a similar mechanism to sucralfate suggests that the aluminium component of sucralfate may be responsible for its action on alkali secretion. In solution, sucralfate undergoes dissociation with the release of aluminium, some of which may be in the form of complex ions. ${ }^{14}$ In the current study, the concentration of aluminium used was comparable with that present from sucralfate but probably exceeded the aluminium that dissociated from sucralfate in solution. Nevertheless, the other components of sucralfate, sucrose sulphate and sucrose octasulphate, did not influence gastroduodenal alkalinization in quantities comparable with those found in the drug suggesting that it is the aluminium content of sucralfate which is important. This contrasts with the mucosal protection afforded by sucralfate on oesophageal epithelium against acid injury which appears dependant on sucrose octasulphate. ${ }^{15}$ As oesophageal mucosa does not secrete bicarbonate in significant quantities, however, it is unlikely that the protective effect of the drug in this tissue would be by the same mechanism.

There is evidence that sucralfate's action on gastroduodenal defence may be mediated by increased production of locally formed protective prostaglandins. Because exogenous prostaglandins of the $E_{2}$ and $F_{2}$ series have been shown to stimulate gastroduodenal bicarbonate secretion and suppression of endogenous prostanoid synthesis leads to its inhibition, ${ }^{16}$ it seemed possible that the action of sucralfate (and aluminium) could be mediated by enhanced prostaglandin formation. A number of early observations were not compatible with this hypothesis, however. First, stimulation of duodenal bicarbonate secretion by exogenous prostaglandins occurs by an electrogenic mechanism and is therefore accompanied by an increase in the transmucosal potential difference. ${ }^{12}$ Second, the potency of prostaglandins on duodenal mucosa is normally greater than on gastric mucosa, the magnitude of the secretory response to applied prostaglandins being much greater. ${ }^{13}$ In the sucralfate experiments, the converse was observed with the duodenal alkali response being smaller than the gastric. The indomethacin experiments provided further evidence that the secretory response to sucralfate was prostaglandin independant. In concentrations believed to abolish cyclooxygenase activity $\left(10^{5} \mathrm{M}\right)$, indomethacin failed to prevent the alkali response to sucralfate and aluminium by gastroduodenal mucosa. Therefore, although other protective mechanisms may be influenced by sucralfate's or aluminium's action on local prostanoid formation, there is no evidence that the bicarbonate response is dependent on such a mechanism. The same conclusion also seems to apply to stimulation of mucus production by sucralfate. ${ }^{17}$

The action of sucralfate and aluminium on gastroduodenal alkali secretion would serve to enhance the protection afforded by the 'mucus-bicarbonate' barrier. Because sucralfate has been shown to influence other components of mucosal defence ${ }^{17}$ it seems likely that its protective action may be mediated by a number of different mechanisms. The relative importance of each defence mechanism activated and whether effects on certain zones would protect against a specific noxious agent are issues which remain unanswered. The finding that aluminium per se is a stimulant of gastroduodenal bicarbonate secretion is also of interest in that aluminium containing antacids have been shown to protect mucosa by effects independant of acid neutralisation and bile salt binding. ${ }^{10}$ It is therefore conceivable that enhancement of the 'mucusbicarbonate' barrier plays a role in this protective action of aluminium containing antacids. 
Dr Crampton is in receipt of a North West Regional Health Authority Grant. The authors wish to thank the Department of Medical Illustration at Hope Hospital who prepared the figures and Mrs S Mayall for secretarial assistance in the preparation of the manuscript.

\section{References}

1 Hollander D, Tarnawski A, Krauser WJ, Gergeley H. Protective effect of sucralfate against alcohol-induced gastric mucosal injury in the rat. Gastroenterology 1985 , 88: $366-74$.

2 Tryba M, Zevoyundu F, Torok M, Zeuz M. Prevention of acute stress bleeding with sucralfate, antacids or cimetidine: a controlled study with pirenzine as a basic medication. Am J Med 1985, 79: suppl 2C: 55-61.

3 Hollander D. Efficacy of sucralfate for duodenal ulcers: A multicenter double-blind trial. J Clin Gastroenterol 1981, 3: supple 2: 153-7.

4 Kagevi I, Anker-Hanson O, Carling L, et al. Swedish Multicenter study on prepyloric and gastric ulcer Scand $J$ Gastroenterol 1987; 22: 67-76.

5 Nakazawa S, Nagashima R, Samloff IM. Selective binding of sucralfate to gastric ulcers in man. Dig Dis Sci 1981 26: 297-300.

6 Samloff IM, O’Dell C. Inhibition of peptic activity by sucralfate. Am J Med 1985; suppl 2C: 15-8.

7 Caspary WF, Graf S. Binding of bile acids by sucralfate and cholestyramine. In: Caspary WE, ed. Sucralfate. A new therapeutic concept. Baltimore, Durban and Schwartzenberg, 1981: 32-8.

8 Hollander D, Tarnawski A, Gergely H, Zipser RD. Sucralfate protection of the gastric mucosa against ethanol induced injury: A prostaglandin mediated process? Scand J Gastroenterol 1984; 19: suppl 10: 97-102.
9 Hollander D, Tarnawski A, Cummings D, Krause WJ, Gergely $H$, Zipser RD. Cytoprotective action of antacids against alcohol induced gastric mucosal injury: morphologic, ultra structural and functional time sequence analysis. Gastroenterology 1985; 86: 1114.

10 Rees WDW, Turnberg LA. Mechanisms of gastric mucosal protection: A role for the mucus-bicarbonate barrier. Clin Sci 1982; 62: 343-8.

11 Flemstrom G. Active alkalinisation by amphibian gastric fundic mucosa in vitro Am J Physiol 1977; 233: E1-12.

12 Flemstrom G. Stimulation of $\mathrm{HCO}_{3}$ transport in isolated proximal bullfrog duodenum by prostaglandins Am J Physiol 1980; 230: G183-93.

13 Flemstrom G, Garner A. Gastroduodenal $\mathrm{HCO}_{3}$ transport: characteristics and proposed role in acidity regulation and mucosal protection. Am J Physiol 1982; 242: G183-93.

14 Nagashima R, Yoshida N. Sucralfate. A basic aluminium salt of sucrose sulphate. Behaviours in gastroduodenal pH. Arzneimitel-Forschung Drug Res 1979; 29: 1668-76.

15 Orlando RC, Turjman NA, Tobey NA, Schreiner VJ, Powell DW. Mucosal protection by sucralfate and its components in acid-exposed rabbit oesophagus. Gastroenterology 1987; 93: 352-61.

16 Garner A, Flemstrom G, Heylings JR. Effects of antiinflammatory agents and prostaglandins on acid and bicarbonate secretion in the amphibian isolated mucosa. Gastroenterology 1979; 77: 451-7.

17 Shea-Donohue T, Steel L, Montcalm E, Dubois A. Gastric protection by sucralfate: Role of mucus and prostaglandins. Gastroenterology 1986; 91: 660-6.

18 Walan A. Antacids and anticholonergics in the treatment of duodenal ulcer. Clin Gastrolenterol 1984; 13: 473-99. 